\title{
AIR POLLUTION AND RESPIRATORY INFECTION IN CHILDREN
}

\author{
BY \\ J. W. B. DOUGLAS \\ Medical Research Council, Unit for the Study of Environmental Factors in Mental and Physical Illness, \\ London School of Economics, \\ AND \\ R. E. WALLER \\ Medical Research Council, Air Pollution Research Unit, St Bartholomew's Hospital Medical College, London
}

The children whose respiratory illnesses are described in this paper were all born during the first week of March, 1946, and have been reported on at intervals by health visitors, school nurses, school doctors, and teachers. A full description of the survey will be found elsewhere (Douglas, 1964). In 1961, when the children were 15 years old, 4,592 of the original survey sample $(5,362)$ were living in Great Britain and information on air pollution is available for 3,866 of them.

The object of this analysis is to examine the relationship between respiratory infections and prolonged sojourn in areas of high or low pollution. The effects of sudden increases in air pollution, such as occurred, for example, in the London fog of 1952. are not under discussion; they are known to be associated with a heavy toll of deaths in infancy as well as in middle or old age. The effects of prolonged exposure to polluted air, which are the subject of this paper, are less clear.

\section{Avallable INFORMATION \\ (a) Assessment of Air Pollution Levels}

Since the children lived in widely scattered parts of the country, the actual measurement of air pollution in each locality was impracticable and an index was sought which could be readily determined everywhere. Daly (1959) used indices of domestic coal consumption and industrial coal consumption in a study of air pollution and causes of death in county boroughs: these were based on figures collected by Local Fuel Overseers during the last year of coal rationing (1951/52). He took into account the amount of fuel, the area within which it was consumed, the type of coal and, to some extent, the shape of each town; his domestic index was expressed in terms of tons of smoke produced per annum per acre of built-up area. The same coal consumption data were used later by the Warren Spring Laboratory (Ministry of Technology, 1966) to classify a much wider range of towns in Great Britain so that a sample of them could be drawn for inclusion in the National Survey. For this purpose it was impracticable to determine the extent of the built-up areas everywhere and each town or village which could be identified separately was classified in terms of its coal consumption per unit area, using the total area of land within its boundaries. We have used the following domestic coal consumption categories, as defined by the Warren Spring Laboratory, as the basis of our present classification:

Domestic Coal
Consumption
D1 (Low)
D2 (Medium)
D3 (High)

Tons/sq. ml.|annum

$$
\begin{gathered}
0-999 \\
1,000-6,999 \\
7,000 \text { and over }
\end{gathered}
$$

As we required only a broad classification into three or four pollution levels, we did not assess industrial pollution separately, nor did we draw up any detailed classification to allow for variations in dispersion characteristics. Instead, the domestic coal consumption was taken as a guide to the amount of pollution of all types and minor modifications were made to allow for unusual local conditions. In particular, Cardiff, Newport, and Swansea were 
placed one level lower than indicated by the Warren Spring figures, since the local coal produces relatively little pollution, and some mining areas, plus Sheffield and all areas in conurbations, were placed one level higher. This procedure then yielded four pollution levels which, broadly speaking, covered the following types of area:

Group $A$

Very low pollution: Rural areas and some small towns Group B

Low pollution:

Other towns under 200,000 population, some mining villages, and fringe areas of conurbations

Group C

Moderate pollution: Large towns, mainly in the range $200,000-500,000$ population, and some mining areas

\section{Group D}

High pollution: Densely populated parts of conurbations

The coal consumption figures used in assessing these levels referred to the year ending May, 1952, when the children were 5 to 6 years old. The present paper includes information on the health of the children up to the age of 15 , but the same pollution levels have been used throughout. The addresses of the children were recorded on eight occasions between 1946 and 1957 and each area where a child had lived was considered separately. All the assessments applied to the towns in which the children lived rather than to the actual street where their homes lay, but this was considered to give an adequate guide to their exposure. We could not in any case take account of the daily movements of children who, for example, live in areas of high pollution and go to school in less polluted ones.

A discussion of the validity of these pollution levels is given in Appendix $\mathrm{I}$.

\section{(b) Information on Illness}

The health visitors, during interviews with the mothers when the children were 2 and 4 years old, asked about both upper and lower respiratory illness and recorded hospital admissions from these or any other causes. The questions asked are given in Appendix II. All hospital admissions recorded were later checked with the hospitals concerned.

The school doctors gave the children special medical examinations at $6,7,11$, and 15 years of age. The mothers attended these examinations with their children and were questioned by the doctors about their children's colds and coughs. They also gave information about hospital admissions. During the physical examinations the doctors were asked to record any râles, rhonchi, or other abnormal chest sounds, and to describe the upper respiratory passages and the tonsils. The relevant questions are given in Appendix II.

During four of the years when the children were at primary schools (from $6 \frac{1}{2}$ to $10 \frac{1}{2}$ ) special absence records were kept by the teachers and the causes of all absences of more than one week were checked with the mothers during the home visit.

\section{RESULTS}

The following account is limited to the 3,131 families who, throughout the first 11 years of this inquiry, either remained at the same address or moved to other areas in the same pollution group as the one they had left. When the study was originally planned it had been intended to look particularly at children who had been subjected to different levels of air pollution to see, for example, what happened to a chesty child when he moved to a less polluted area after spending his early years in one of high pollution. However, since 81 per cent. of the families remained throughout the whole survey period in areas which were within the same pollution category, there were too few changes in exposure to pollution to allow us to carry out the more detailed studies originally contemplated. The number of children in each group of areas at the beginning of the study, and the proportion who from birth to 11 years lived at addresses within the same group is given in Table $I$.

TABLE I

NUMBERS OF CHILDREN BORN IN FOUR AREAS CLASSIFIED BY CATEGORY OF AIR POLLUTION AND NUMBERS AND PROPORTION LIVING IN THE SAME TYPE OF AREA FROM BIRTH UNTIL 11 YEARS

\begin{tabular}{c|c|c|c|c|c}
\hline & \multicolumn{5}{|c|}{ Air Pollution Group } \\
\cline { 2 - 6 } Children & $\begin{array}{c}\text { A } \\
\text { Very } \\
\text { Low }\end{array}$ & $\begin{array}{c}\text { B } \\
\text { Low }\end{array}$ & $\begin{array}{c}\text { C } \\
\text { Mod- } \\
\text { erate }\end{array}$ & $\begin{array}{c}\text { D } \\
\text { High }\end{array}$ & Total \\
\hline $\begin{array}{l}\text { Number born and surviv- } \\
\text { ing .. . . . } \\
\text { Number in same pollution } \\
\text { group from birth until } \\
11 \text { years }\end{array}$ & 728 & 1,240 & 1,024 & 874 & 3,866 \\
Proportion in same group & 565 & 1,032 & 829 & 705 & 3,131 \\
\end{tabular}

Table II (opposite) shows for each level of air pollution the proportion of children who come from different social classes*.

The four distributions are similar, and there is no tendency for the poorer families to be concentrated in the more heavily polluted areas. That this should be so simplifies problems of analysis, for it means

* A definition of these social classes is given in The Home and the School pp. 44 and 45. 
that any differences found between the areas are unlikely to be explained by the very small differences in social composition which occur. A study of the housing conditions in the four areas shows no consistent differences, and there is no reason to believe that any excess of serious respiratory infections which might be found in the heavily polluted areas could be explained in terms of overcrowding.

TABLE II

SOCIAL CLASS COMPOSITION (per cent.) OF FOUR AREAS CLASSIFIED BY CATEGORY OF AIR POLLUTION

\begin{tabular}{|c|c|c|c|c|}
\hline \multirow[b]{2}{*}{ Social Class } & \multicolumn{4}{|c|}{ Air Pollution Group } \\
\hline & $\stackrel{\mathbf{A}}{\text { Very Low }}$ & $\begin{array}{l}\text { B } \\
\text { Low }\end{array}$ & $\begin{array}{c}\mathbf{C} \\
\text { Moderate }\end{array}$ & $\underset{\text { High }}{\mathrm{D}}$ \\
\hline $\begin{array}{l}\text { Middle } \\
\text { Class }\end{array}\left\{\begin{array}{l}\text { Upper } \\
\text { Lower }\end{array}\right.$ & $\begin{array}{l}12 \cdot 2 \\
25 \cdot 0\end{array}$ & $\begin{array}{l}13 \cdot 7 \\
30 \cdot 4\end{array}$ & $\begin{array}{l}10 \cdot 8 \\
31 \cdot 9\end{array}$ & $\begin{array}{l}10 \cdot 0 \\
29 \cdot 6\end{array}$ \\
\hline Manual $\int$ Upper & $19 \cdot 8$ & $18 \cdot 6$ & $16 \cdot 5$ & $17 \cdot 7$ \\
\hline Class Lower & $43 \cdot 0$ & $37 \cdot 3$ & $40 \cdot 8$ & $42 \cdot 7$ \\
\hline Total .. & $100 \cdot 0$ & $100 \cdot 0$ & $100 \cdot 0$ & $100 \cdot 0$ \\
\hline
\end{tabular}

(a) Upper Respiratory Tract Infections (running noses, discharging ears, tonsils removed or needing removal).-Table III presents the information reported by the health visitors and school doctors on colds and running noses. There is a slight tendency, which is not statistically significant, for the first reported cold to occur earlier among children living in the more polluted areas (Groups C and D) than among children living in the less polluted ones (Groups A and B). Otherwise there is no suggestion

TABLE III

UPPER RESPIRATORY TRACT INFECTION (per cent.) BY CATEGORY OF AIR POLLUTION

\begin{tabular}{|c|c|c|c|c|}
\hline \multirow[b]{2}{*}{ Upper Respiratory Tract Infection } & \multicolumn{4}{|c|}{ Air Pollution Group } \\
\hline & $\begin{array}{l}\text { A } \\
\text { Very } \\
\text { Low }\end{array}$ & $\begin{array}{c}\text { B } \\
\text { Low }\end{array}$ & $\begin{array}{c}\text { Moder- } \\
\text { ate }\end{array}$ & $\begin{array}{c}\text { D } \\
\text { High }\end{array}$ \\
\hline (a) First cold before age of $10 \mathrm{mths}$ & $62 \cdot 6$ & $61 \cdot 4$ & $67 \cdot 2$ & $66 \cdot 3$ \\
\hline $\begin{array}{c}\text { (a) More than } 2 \text { colds between } 21 \\
\text { and } 23 \mathrm{mths} . .\end{array}$ & $17 \cdot 7$ & $16 \cdot 0$ & $16 \cdot 1$ & $18 \cdot 2$ \\
\hline $\begin{array}{l}\text { (a) Frequent or continual colds be- } \\
\text { tween } 46 \text { and } 51 \text { mths }\end{array}$ & $14 \cdot 6$ & $16 \cdot 1$ & $14 \cdot 8$ & $16 \cdot 0$ \\
\hline $\begin{array}{l}\text { *(b) Running nose, snoring, mouth } \\
\text { breathing and sore throat age } \\
5 \text { to } 6 \text { yrs } \quad . . \quad \ldots \quad \text {.. }\end{array}$ & $12 \cdot 3$ & $8 \cdot 8$ & $13 \cdot 3$ & $12 \cdot 3$ \\
\hline (c) Mucopurulent discharge 6 yrs & $14 \cdot 2$ & $15 \cdot 7$ & $13 \cdot 0$ & $13 \cdot 6$ \\
\hline $\begin{array}{l}\text { "(b) Running nose, snoring, mouth } \\
\text { breathing and sore throat age } \\
6 \text { to } 7 \mathrm{yrs} \quad . .\end{array}$ & $12 \cdot 6$ & $9 \cdot 7$ & $12 \cdot 4$ & $12 \cdot 3$ \\
\hline (c) Mucopurulent discharge 7 yrs & $13 \cdot 2$ & $15 \cdot 9$ & $14 \cdot 2$ & $15 \cdot 9$ \\
\hline
\end{tabular}

(a) Mothers' reports to health visitors.

(b) Mothers' reports to school doctors.

(c) Recorded at examinations by school doctors.

These children show all four symptoms or signs. that colds are more common in the more polluted areas at any time during the first seven years of life. The agreement between information derived from three sources-the mothers' reports to health visitors, the histories given by mothers to school doctors, and the results of the school doctors' examination of the nasal passages-is excellent.

The reports on discharging ears (Table IV) show only minor differences between the four groups of areas, and these are not statistically significant. There is, however, a consistent tendency at each age for a larger proportion of the children living in the more polluted areas (Group D) to have discharging ears.

\section{TABLE IV}

DISCHARGING EARS (per cent.) BY CATEGORY OF AIR POLLUTION

\begin{tabular}{|c|c|c|c|c|}
\hline \multirow[b]{2}{*}{ Ears discharging at or before } & \multicolumn{4}{|c|}{ Air Pollution Group } \\
\hline & $\begin{array}{c}\text { A } \\
\text { Very } \\
\text { Low }\end{array}$ & $\begin{array}{c}B \\
\text { Low }\end{array}$ & $\underset{\substack{\text { Moder- } \\
\text { ate }}}{\mathbf{C}}$ & $\begin{array}{c}\text { D } \\
\text { High }\end{array}$ \\
\hline $\begin{array}{l}2 \text { yrs } \\
4 \text { yrs } \\
6 \text { yrs }\end{array}$ & $\begin{array}{r}4 \cdot 6 \\
10.9 \\
17.8\end{array}$ & $\begin{array}{r}5.3 \\
11.4 \\
17.4\end{array}$ & $\begin{array}{r}3 \cdot 9 \\
9.0 \\
18.2\end{array}$ & $\begin{array}{r}6 \cdot 3 \\
13 \cdot 4 \\
21 \cdot 0\end{array}$ \\
\hline
\end{tabular}

Table $\mathrm{V}$ shows the proportion of children who, at 6,11 , or 15 years, had had their tonsils removed or whose tonsils, according to the school doctor, needed removal. The latter were included to offset any differences in the availability of hospital beds for tonsillectomy in the four areas. Again, the differences between the four groups of areas are small and not statistically significant, though there is a tendency at each age for the children living in the Group A areas to keep their tonsils or, in the school doctor's opinion, to have healthy tonsils.

\section{TABLE V}

TONSILLECTOMIES OR TONSILS NEEDING REMOVAL (per cent.) BY CATEGORY OF AIR POLLUTION

\begin{tabular}{|c|c|c|c|c|}
\hline \multirow{2}{*}{$\begin{array}{l}\text { Tonsils removed or } \\
\text { needing removal at }\end{array}$} & \multicolumn{4}{|c|}{ Air Pollution Group } \\
\hline & $\begin{array}{c}\text { A } \\
\text { Very } \\
\text { Low }\end{array}$ & $\begin{array}{c}\text { B } \\
\text { Low }\end{array}$ & $\begin{array}{c}\text { Moder- } \\
\text { ate }\end{array}$ & $\begin{array}{c}\text { D } \\
\text { High }\end{array}$ \\
\hline $\begin{array}{r}6 \mathrm{yrs} \\
11 \mathrm{yrs} \\
15 \mathrm{yrs}\end{array}$ & $\begin{array}{l}16 \cdot 2 \\
22 \cdot 8 \\
22 \cdot 9\end{array}$ & $\begin{array}{l}22 \cdot 0 \\
28 \cdot 6 \\
31 \cdot 2\end{array}$ & $\begin{array}{l}22 \cdot 0 \\
27 \cdot 0 \\
29 \cdot 2\end{array}$ & $\begin{array}{l}21 \cdot 2 \\
29.9 \\
31 \cdot 4\end{array}$ \\
\hline
\end{tabular}

To sum up the information on upper respiratory tract illness, there is no statistically significant evidence to suggest that the level of air pollution is related to the frequency of colds or discharging ears up to the age of 7, or to tonsillar infection or removal up to the age of 15 , though there is a tendency for each of these conditions to be reported less frequently in the areas with the lower levels of air pollution. 
(b) Lower Respiratory Tract Infections (Coughs, bronchitis, bronchopneumonia, lobarpneumonia).The reports on lower respiratory tract infections during the first two years of life give an entirely different picture from those on upper respiratory tract infections. Table VI shows that, in both the first and second year of life, lower respiratory tract illness is more likely to be reported for children living in areas of high pollution, and that there is a steady gradient running from a relatively low level of respiratory tract disease in the Group A areas to a relatively high level in the Group $D$ areas. This gradient is particularly marked for children who had more than one episode of lower respiratory tract illness during the first two years of life; using this criterion, those living in Group D areas have three times the amount of illness reported for those in Group A. All these differences are statistically highly significant and point to an increasing severity of respiratory illness as pollution increases. Moreover, as shown in the last four lines of Table VI, similar gradients of lower respiratory tract disease are found for boys and girls and for middle class and manual working class children.

The mothers' reports on coughs are confirmed by our data for children admitted to hospital. The majority of admissions for respiratory tract infections occur in the first five years of life, and Table VII is restricted to admissions during this period. Admissions for acute upper respiratory tract infections and for tonsillitis or tonsillectomy show neither a consistent nor a statistically significant association with the level of air pollution, whereas admissions for lower respiratory infections, i.e. bronchitis and pneumonia, do.
TABLE VII

HOSPITAL ADMISSIONS (per cent.) FOR RESPIRATORY TRACT INFECTIONS DURING THE FIRST 5 YEARS OF LIFE BY CATEGORY OF AIR POLLUTION

\begin{tabular}{|c|c|c|c|c|}
\hline \multirow{2}{*}{ Reason for Hospital Admission } & \multicolumn{4}{|c|}{ Air Pollution Group } \\
\hline & $\begin{array}{l}\text { A } \\
\text { Very } \\
\text { Low }\end{array}$ & $\begin{array}{c}\text { B } \\
\text { Low }\end{array}$ & $\underset{\substack{\text { Moder- } \\
\text { ate }}}{\mathbf{C}}$ & $\begin{array}{c}\text { D } \\
\text { High }\end{array}$ \\
\hline $\begin{array}{c}\text { Acute upper respiratory } \\
\text { infections } \ldots\end{array}$ & 0.4 & $0 \cdot 3$ & 0.4 & $1 \cdot 1$ \\
\hline Tonsillitis and tonsillectomy & $4 \cdot 4$ & $6 \cdot 2$ & $5 \cdot 7$ & $5 \cdot 2$ \\
\hline $\begin{array}{l}\text { Lower respiratory infections* } \\
\text { (a) Bronchitis a } \\
\text { (b) Pneumonia and broncho- } \\
\text { pneumonia .. }\end{array}$ & $\begin{array}{l}1 \cdot 1 \\
\text { nil } \\
1 \cdot 1\end{array}$ & $\begin{array}{l}2 \cdot 3 \\
0.9 \\
1.4\end{array}$ & $\begin{array}{l}2 \cdot 6 \\
1 \cdot 0 \\
1 \cdot 6\end{array}$ & $\begin{array}{l}3 \cdot 1 \\
1 \cdot 4 \\
1 \cdot 8\end{array}$ \\
\hline
\end{tabular}

* Comparing children in area " $\mathrm{A}$ " with those in areas " $\mathrm{B}$ ", " $\mathrm{C}$ " and " $D " \chi^{2}=4.06 ; n=1 ; 0.05>P>0.02$.

The school doctors, as already mentioned, examined the survey children when they were 6,7 , 11 , and 15 years of age and were asked to listen to their chests. On each occasion râles or rhonchi were heard by a few doctors; Table VIII (opposite) summarizes their reports on these signs and relates them to the amount of air pollution. In passing from Group A to Group D, the proportion of children with râles or rhonchi (heard on one or more occasions) increases. The last line of Table VIII gives the results of the examination at 15 years, which suggests that the effects of air pollution on the lower respiratory tract persist at least into later school life.

The evidence so far suggests that lower respiratory tract illness, in contrast to upper respiratory tract illness, is most frequent and most severe among children living in the most polluted areas. This holds equally for boys and girls and for middle and manual working class children.

TABLE VI

LOWER RESPIRATORY TRACT INFECTIONS (per cent.) IN INFANCY BY CATEGORY OF AIR POLLUTION

\begin{tabular}{|c|c|c|c|c|c|c|c|}
\hline \multirow{2}{*}{\multicolumn{2}{|c|}{$\begin{array}{l}\text { Lower Respiratory Tract } \\
\text { Infections }\end{array}$}} & \multicolumn{4}{|c|}{ Air Pollution Group } & \multicolumn{2}{|c|}{ Significance } \\
\hline & & $\stackrel{A}{A}$ & $\begin{array}{l}\text { B } \\
\text { Low }\end{array}$ & $\stackrel{\mathrm{C}}{\text { Moderate }}$ & $\underset{\text { High }}{\mathrm{D}}$ & $\chi^{2}(n=3)$ & $\mathbf{P}$ \\
\hline First attack in first $9 \mathrm{mths}$ & . & $7 \cdot 2$ & $11 \cdot 4$ & $16 \cdot 5$ & $17 \cdot 1$ & $35 \cdot 342$ & $<0.001$ \\
\hline \multicolumn{2}{|l|}{ At least one attack in first $2 \mathrm{yrs}$} & $19 \cdot 4$ & $24 \cdot 2$ & $30 \cdot 0$ & $34 \cdot 1$ & $39 \cdot 800$ & $<0.001$ \\
\hline \multicolumn{2}{|c|}{ More than one attack in first $2 \mathrm{yrs}$} & $4 \cdot 3$ & $7 \cdot 9$ & $11 \cdot 2$ & $12 \cdot 9$ & $31 \cdot 887$ & $<0.001$ \\
\hline \multirow[t]{2}{*}{$\begin{array}{l}\text { More than one attack in first } \\
2 \text { yrs }\end{array}$} & Boys & $5 \cdot 7$ & $8 \cdot 1$ & $10 \cdot 9$ & $16 \cdot 2$ & $21 \cdot 574$ & $<0.001$ \\
\hline & Girls .. & $2 \cdot 9$ & $7 \cdot 7$ & $12 \cdot 1$ & $9 \cdot 7$ & $18 \cdot 884$ & $<0.001$ \\
\hline \multirow[t]{2}{*}{$\begin{array}{l}\text { More than one attack in first } \\
2 \text { yrs }\end{array}$} & $\begin{array}{l}\text { Middle } \\
\text { Class .. }\end{array}$ & $3 \cdot 0$ & $4 \cdot 0$ & $7 \cdot 7$ & $9 \cdot 3$ & $12 \cdot 701$ & $0.01-0.001$ \\
\hline & $\begin{array}{l}\text { Manual } \\
\text { Working } \\
\text { Class .. }\end{array}$ & $5 \cdot 1$ & $10 \cdot 8$ & $13 \cdot 9$ & $15 \cdot 4$ & $22 \cdot 092$ & $<0.001$ \\
\hline
\end{tabular}


TABLE VIII

RÂLES OR RHONCHI (per cent.) RECORDED AT MEDICAL EXAMINATIONS (6, 7, 11, AND 15 YEARS) BY CATEGORY OF AIR POLLUTION

\begin{tabular}{|c|c|c|c|c|c|c|}
\hline \multirow[b]{2}{*}{ Examinations at $6,7,11$, and 15 yrs } & \multicolumn{4}{|c|}{ Air Pollution Group } & \multicolumn{2}{|c|}{ Significance } \\
\hline & $\stackrel{A}{\text { Very Low }}$ & $\begin{array}{c}\text { B } \\
\text { Low }\end{array}$ & $\underset{\text { Moderate }}{\mathrm{C}}$ & $\underset{\text { High }}{\mathbf{D}}$ & $\chi^{2}(n=3)$ & $\mathbf{P}$ \\
\hline $\begin{array}{l}\text { Rales or rhonchi recorded on one or } \\
\text { more occasions } \\
\text { Rales or rhonchi recorded on two or } \\
\text { more occasions } \\
\text { Rales or rhonchi recorded at } 15 \text {-year } \\
\text { examination } \ldots\end{array}$ & $\begin{array}{r}10.8 \\
0.5 \\
0.2\end{array}$ & $\begin{array}{r}13 \cdot 7 \\
2 \cdot 1 \\
1 \cdot 2\end{array}$ & $\begin{array}{r}17 \cdot 5 \\
2 \cdot 5 \\
2 \cdot 1\end{array}$ & $\begin{array}{r}17 \cdot 3 \\
2 \cdot 7 \\
2 \cdot 2\end{array}$ & $\begin{array}{r}11 \cdot 947 \\
7 \cdot 292 \\
9 \cdot 706\end{array}$ & $\begin{array}{r}0.02-0.01 \\
0.1-0.05 \\
0.05-0.02\end{array}$ \\
\hline
\end{tabular}

(c) Information from School Absences.-This information for children between $6 \frac{1}{2}$ and $10 \frac{1}{2}$ years is of two kinds. One gives the total number of episodes of absence and the total number of weeks of absence over the 4-year period during which records were kept, and the other gives the causes of absences and their frequency for all episodes which lasted more than one week. Table IX sets out the total figures for episodes and weeks of absence and shows the proportion of children who had an excess of absence on the arbitrary criterion that their total absences over the four years lay more than $1 \frac{1}{2}$ standard deviations above the average for all children. The excess among children in the most polluted areas is more evident when the absence is given in episodes. This suggests that the level of air pollution is related to the number of short-term absences from school rather than to the total amount of absence.

The causes of the longer absences, i.e. of more than one week's duration, are set out in Table X. Colds and influenza are equally common causes of lengthy absence in each of the four pollution areas, and though absences from bronchitis increase progressively from Group A to Group D, this trend is not statistically significant. It is likely that the figures for long absences from school overstate absence caused by illness in the areas of low pollution as these are mainly rural districts where the distances to be travelled may discourage some mothers from sending
TABle $X$

LONG PERIODS OF ABSENCE IN PRIMARY SCHOOLS BY CATEGORY OF AIR POLLUTION

\begin{tabular}{|c|c|c|c|c|}
\hline \multirow{3}{*}{$\begin{array}{l}\text { Reasons for } \\
\text { Absence }\end{array}$} & \multicolumn{4}{|c|}{$\begin{array}{l}\text { Percentage in each group of areas away for } \\
\text { more than one week on one or more occasions }\end{array}$} \\
\hline & \multicolumn{4}{|c|}{ Air Pollution Group } \\
\hline & $\stackrel{A}{\text { Very Low }}$ & $\begin{array}{l}\text { B } \\
\text { Low }\end{array}$ & $\stackrel{\mathrm{C}}{\text { Moderate }}$ & $\underset{\text { High }}{\mathrm{D}}$ \\
\hline $\begin{array}{l}\text { Colds } ; \text { "Influenza" } \\
\text { *Bronchitis }\end{array}$ & $\begin{array}{r}30 \cdot 4 \\
31 \cdot 5 \\
7 \cdot 3\end{array}$ & $\begin{array}{r}25 \cdot 0 \\
27 \cdot 9 \\
9 \cdot 7\end{array}$ & $\begin{array}{r}39 \cdot 6 \\
26.9 \\
9.9\end{array}$ & $\begin{array}{l}29 \cdot 6 \\
26 \cdot 5 \\
11 \cdot 5\end{array}$ \\
\hline
\end{tabular}

$\chi^{2} 4 \cdot 734 ; n=3 ; 0 \cdot 2>P>0 \cdot 1$.

their children back to school as soon as those in the more polluted areas. In spite of this, however, information on absences from school supports that already derived from hospital admissions, school doctors' examinations, and mothers' reports to the health visitors.

\section{SUMmaRY}

As part of the National Survey of Health and Development, information has been obtained on the health of a sample of children from their birth in 1946 until they reached school-leaving age in 1961. The 3,866 children who are the subject of this study had, between them, dwelt in 2,689 different administrative areas since birth. Each of these areas was classified into one of four pollution categories, based primarily on domestic coal consumption in 1952 , and the data on respiratory infection were

TABLE IX

PRIMARY SCHOOL ABSENCES (per cent.) BY CATEGORY OF AIR POLLUTION

\begin{tabular}{|c|c|c|c|c|c|c|c|c|c|}
\hline \multirow{2}{*}{\multicolumn{4}{|c|}{ School Absence }} & \multicolumn{4}{|c|}{ Air Pollution Group } & \multicolumn{2}{|c|}{ Significance } \\
\hline & & & & $\stackrel{A}{\text { Very Low }}$ & $\begin{array}{c}\text { B } \\
\text { Low }\end{array}$ & $\underset{\text { Moderate }}{\mathrm{C}}$ & $\underset{\text { High }}{\text { D }}$ & $x^{2}(n=3)$ & $\mathbf{P}$ \\
\hline $\begin{array}{l}\text { * Excess episodes } \\
\text { * Excess time away }\end{array}$ & $\begin{array}{l}\cdots \\
\cdots\end{array}$ & . & $\begin{array}{l}\cdots \\
\cdots\end{array}$ & $\begin{array}{l}3 \cdot 9 \\
6 \cdot 0\end{array}$ & $\begin{array}{l}5 \cdot 8 \\
6 \cdot 5\end{array}$ & $\begin{array}{l}6 \cdot 5 \\
5 \cdot 2\end{array}$ & $\begin{array}{l}9 \cdot 3 \\
8 \cdot 0\end{array}$ & $\begin{array}{r}12 \cdot 278 \\
3 \cdot 928\end{array}$ & $\begin{array}{r}<0.01 \\
0.3-0.2\end{array}$ \\
\hline \multirow{2}{*}{ * Excess episodes } & \multicolumn{2}{|c|}{$\begin{array}{l}\text { Middle } \\
\text { Class }\end{array}$} & . & $1 \cdot 2$ & $2 \cdot 8$ & $3 \cdot 1$ & $5 \cdot 9$ & $6 \cdot 493$ & $0 \cdot 1-0.05$ \\
\hline & \multicolumn{3}{|c|}{$\begin{array}{l}\text { Manual } \\
\text { Working Class }\end{array}$} & $5 \cdot 3$ & $7 \cdot 9$ & $8 \cdot 8$ & $11 \cdot 7$ & $7 \cdot 901$ & $0.05-0.02$ \\
\hline
\end{tabular}

* Excess in each instance is more than $1 \frac{1}{2}$ standard deviations above the mean. 
analysed with respect to these categories. Comparisons made later between the predicted categories and the measured amounts of pollution in some of the areas showed a satisfactory agreement between the two. The information on illness was obtained during interviews between health visitors and the mothers when the children were aged 2 and 4 years, and during examinations by school doctors when the children were aged $6,7,11$, and 15 years. Hospital admissions were also recorded and special absence records were kept at school when the children were aged $6 \frac{1}{2}$ to $10 \frac{1}{2}$ years.

The results are simple and consistent: upper respiratory tract infections were not related to the amount of air pollution, but lower respiratory infections were so related. The frequency and severity of lower respiratory tract infections increased with the amount of air pollution. Boys and girls were similarly affected, and no difference was found between children in middle class and working class families. An association between lower respiratory tract infection and air pollution was found at each age examined and the results of the school doctors' chest examinations at the age of 15 suggest that it persists at least until school leaving age.

Valuable assistance in the classification of areas with respect to pollution was given by Mrs M-L. P. M. Weatherley of the Warren Spring Laboratory, and by Mrs A. Parrish and Miss R. A. Bailey of the Air Pollution Research Unit. Dr C. M. Fletcher made a number of helpful suggestions.

The National Survey of Health and Development was sponsored by a joint committee of the Institute of Child
Health, the Society of Medical Officers of Health, and the Population Investigation Committee. It is now being directed from the Medical Research Council Unit at the London School of Economics. In its early years the inquiry was financed by the Nuffield Foundation, and grants for continuing it through the school years have come from many sources, including the Ford Foundation and the Population Council, Inc.

A national longitudinal study such as this is only possible because of the generous co-operation we have had from many people and agencies; here we would especially like to thank the directors of education, teachers, and health visitors in all parts of Great Britain, who have given us information about the boys and girls included in this Survey. We should also like to thank the mothers who willingly answered numerous detailed questions, and the boys and girls themselves.

\section{REFERENCES}

Daly, C. (1959). Brit. J. prev. soc. Med., 13, 14.

Department of Scientific and Industrial Research [now Ministry of Technology]. (1955). "The Investigation of Atmospheric Pollution, 27th Report, 1945-54." HMSO, London.

(1964). "The Investigation of Atmospheric Pollution. Tables of Observations for the Year ended March 31, 1963." Warren Spring Laboratory, Stevenage, Herts.

Douglas, J. W. B. (1964). "The Home and the School." MacGibbon and Kee, Aldershot.

Ministry of Technology (1966). "The Investigation of Atmospheric Pollution, 32nd Report, 1958-63." HMSO, London.

Waller, R. E. (1966). Duplicated copies of a list giving the original and revised classification of nearly 2,700 areas in Great Britain may be obtained on request from the MRC Air Pollution Research Unit, St. Bartholomew's Hospital Medical College, London, E.C.1.

\section{APPENDIX I}

\section{Validity of Estimates of Pollution Levels}

\begin{abstract}
Although there were few sites where regular measurements of pollution were made at the beginning of the period covered by this study (1946), the number steadily increased year by year, and now that the National Survey of Smoke and Sulphur Dioxide is in full operation there is sufficient information available to judge how effective our four pollution categories have been as an index either of smoke or of sulphur dioxide. We have used figures published by the Department of Scientific and Industrial Research (1964) for the year ending March, 1963, and the following procedure was adopted in selecting sites for inclusion in the present comparisons:
\end{abstract}

(1) The list of sampling sites was examined to find Local Authority areas where one or more of the survey children had lived; in widely dispersed areas a site was included only if it was close to the address of one of the children.

(2) The site was accepted if the mean annual concentration of smoke was quoted or if sufficient monthly figures were given to enable the mean annual concentration to be estimated reliably.

(3) Where there was more than one site available in the required locality the one reporting the highest smoke concentration was selected. This tended to favour the older residential areas where the conditions may not have changed as much as in other parts of the town. 
(4) Having selected a site on the basis of the smoke concentration, the sulphur dioxide concentration at the same site was also noted, where available.

Smoke concentrations were available for 179 of the 2,689 areas which we had originally classified, and sulphur dioxide concentrations for 151 of these. Each of these areas had been classified into one of the four pollution categories (very low, low, moderate, or high) as for 1952, and the measured concentrations of pollution were available for the year 1962-3.

Mean concentrations of pollution within each category are shown in Appendix Tables A and B. Greater London has been considered separately, since it was known (Ministry of Technology, 1966) that changes in pollution in the London area over the 10-year period involved would have had a serious effect on the assessment.

The concentration of each pollutant increases, as predicted, from one category to the next, and in the case of sulphur dioxide there is no serious discrepancy between the mean concentrations in Greater London and those in other areas. Within each category the concentrations of smoke are, however, lower in Greater London than in other areas. The limited data available on actual concentrations of smoke around 1952 (Department of Scientific and Industrial Research, 1955) suggest that there was then little difference between Greater London and elsewhere, and it seems likely that our

TABLE A

COMPARISON OF PREDICTED POLLUTION CATEGORIES IN 1952 WITH MEASURED CONCENTRATIONS OF SMOKE IN 179 SELECTED AREAS OF GREAT BRITAIN (1962-3)

\begin{tabular}{|c|c|c|c|c|c|}
\hline \multirow{2}{*}{\multicolumn{2}{|c|}{$\begin{array}{l}\text { Measured Concentration of Smoke } \\
(1962-3)\end{array}$}} & \multicolumn{4}{|c|}{ Air Pollution Group* } \\
\hline & & \multirow{2}{*}{$\begin{array}{c}\begin{array}{c}\text { A } \\
\text { Very } \\
\text { Low }\end{array} \\
- \\
-\end{array}$} & \multirow{2}{*}{$\begin{array}{c}\begin{array}{c}\text { B } \\
\text { Low }\end{array} \\
8 \\
91 \\
3 \cdot 3\end{array}$} & \multirow{2}{*}{$\begin{array}{c}\begin{array}{c}\text { C } \\
\text { Moder- } \\
\text { ate }\end{array} \\
6 \\
99 \\
12 \cdot 7\end{array}$} & \multirow{2}{*}{\begin{tabular}{|c|} 
D \\
High
\end{tabular}} \\
\hline $\begin{array}{l}\text { Greater } \\
\text { London }\end{array}$ & $\begin{array}{l}\text { No. of areas included } \\
\text { Mean concentration } \\
\left(\mu \mathrm{g} \cdot / \mathrm{m}^{8}\right) \\
\text { SE of mean }\end{array}$ & & & & \\
\hline $\begin{array}{l}\text { Other } \\
\text { Areas }\end{array}$ & $\begin{array}{l}\text { No. of areas included } \\
\text { Mean concentration } \\
\left(\mu \mathrm{g} . / \mathrm{m}^{2}\right) \\
\text { SE of mean }\end{array}$ & $\begin{array}{l}17 \\
67 \\
10 \cdot 6\end{array}$ & $\begin{array}{c}56 \\
138 \\
9 \cdot 2\end{array}$ & $\begin{array}{c}51 \\
217 \\
11 \cdot 4\end{array}$ & $\begin{array}{c}14 \\
281 \\
19 \cdot 6\end{array}$ \\
\hline
\end{tabular}

* Predicted in 1952. classification provides a reasonable guide to the variations in concentration of both smoke and sulphur dioxide in all areas at that time.

On the basis of the 1962-3 figures, there was considerable overlap between our categories. In Greater London the differences between the mean concentrations of both smoke and sulphur dioxide in categories $B$ and $C$ was not significant; other differences between means were significant at the 5 per cent. level, but within each category there were some areas that appeared to have been wrongly classified, even when changes in pollution between 1952 and 1962 were taken into account. In particular we had overestimated the pollution of some towns in the South having favourable dispersion conditions and underestimated that of some small industrial towns in the North. The effect of these errors on the results of the present study is small, since few of the children lived in the towns that had been wrongly classified. The defects in our procedure could be removed by making more use of the data on dispersion conditions and industrial coal consumption collected by the Warren Spring Laboratory. We are now revising our classification (Waller, 1966), for it may be useful in other studies relating to conditions about 10 years ago; for current conditions it would be possible to devise a scale based directly on recent measurements made for the National Survey of Smoke and Sulphur Dioxide.

TABLE B

COMPARISON OF PREDICTED POLLUTION CATEGORIES IN 1952 WITH MEASURED CONCENTRATIONS OF SULPHUR DIOXIDE IN 151 SELECTED AREAS OF GREAT BRITAIN (1962-3)

\begin{tabular}{|c|c|c|c|c|c|}
\hline \multirow{2}{*}{\multicolumn{2}{|c|}{$\begin{array}{l}\text { Measured Concentration of } \\
\text { Sulphur Dioxide (1962-3) }\end{array}$}} & \multicolumn{4}{|c|}{ Air Pollution Group* } \\
\hline & & $\mathbf{A}$ & B & & D \\
\hline $\begin{array}{l}\text { Greater } \\
\text { London }\end{array}$ & $\begin{array}{l}\text { No. of areas included } \\
\text { Mean concentration } \\
\left(\mu \mathrm{g} . / \mathrm{m}^{2}\right) \\
\text { SE of mean } . \quad .\end{array}$ & - & $\begin{array}{c}8 \\
148 \\
8 \cdot 5\end{array}$ & $\begin{array}{c}6 \\
181 \\
29 \cdot 5\end{array}$ & $\begin{array}{c}24 \\
249 \\
14 \cdot 6\end{array}$ \\
\hline $\begin{array}{l}\text { Other } \\
\text { Areas }\end{array}$ & $\begin{array}{l}\text { No. of areas included } \\
\text { Mean concentration } \\
\left(\mu g . / m^{2}\right) \\
\text { SE of mean } . \quad .\end{array}$ & $\begin{array}{l}14 \\
90 \\
14 \cdot 5\end{array}$ & $\begin{array}{c}46 \\
130 \\
8 \cdot 7\end{array}$ & $\begin{array}{c}43 \\
191 \\
12 \cdot 5\end{array}$ & $\begin{array}{r}10 \\
257 \\
27 \cdot 4\end{array}$ \\
\hline
\end{tabular}

* Predicted in 1952. 


\section{APPENDIX II}

\section{A. Questions asked by Health Visitors} At 2 years of Age

(1) COLDS

(a) At what age did this baby have his first cold?

(b) How many colds has he had during the three months December 1, 1947, to March 1, 1948 ?

(2) COUGHS

(c) Has this baby ever had a lower respiratory infection i.e. bronchitis, broncho-pneumonia or pneumonia?

If "yes":

(i) How many months old was baby when he first had the lower respiratory infection?

(ii) How many times has he had a lower respiratory infection?

(iii) Where or by whom was he treated?

\section{At 4 years of Age}

(3) COLDS

(d) Please give the following details about this child's colds since Christmas, 1949 (i.e. during the last 3 months).

(i) Has he had continual colds? (ii) Has he had frequent colds? (4 or more)

(iii) Has he had occasional colds ? (less than 4)

(iv) Has he had no colds?

\section{B. Doctors' Examination}

(1) EXAMINATION OF NASAL PASSAGES (at 6 and 7 years)

(a) Is there a nasal discharge?

(b) Is it watery or mucopurulent ?

(c) Is there a post-nasal discharge hanging down behind the uvula?

(d) Are this child's nasal passages obstructed?

(2) COLDS, SORE THROATS, ETC. (questions by the school doctor to the mother at the 6 and 7 year examination)

(a) Does this child breathe with his mouth open in the day time?

(b) Does he snore at night?

(c) How often has he had a snuffly or running nose during the last year?

(d) Has he had a sore throat during the last year? If so, how many has he had? 